Yhden vahvan ja vähän Suomessa sovelletun metodin asettaminen tutkimuksen rungoksi tekee tutkimuksesta koherentin ja teoriataustaltaan tuoreen. Väitöskirja on rohkea ja luova, mikä näkyy myös Kurikan kirjoitustyylissä. Kääntöpuolena yhden vahvan ja omaleimaisen teorian soveltamisessa on se, että monimutkainen kehikko uhkaa hukuttaa alleen itse asian eli Untolan moninimisen tekijyyden avaamisen. Tutkimus lähtee liikkeelle odotetusta lupauksesta uudistaa Barthesin ja Foucault'n teesien jäljillä yhäkin roikkuvaa tekijätutkimusta, mutta metodin haastavuus ei rohkaise sen soveltamiseen. Välillä pohdin, auttaako käytetty teoria minua ymmärtämään Untolan tekijyyden elementtejä vai tekeekö se ymmärtämisestä vain hankalampaa.

Untolan tekijäpolitiikan äärimmäinen kompleksisuus tulee havainnollistavasti esiin väitöskirjassa. Teos aiheuttaa varsinaisen tornadon jatkoajatuksia ja uusia ideoita, sillä niin Deleuzen ja Guattarin kuin Kurikankin muotoilut antavat tilaa lukijan omille tulkinnoille. Kysymyksiä tulee mieleen sen verran paljon, että tilausta olisi vaikka kansainväliseen tyyliin haastatteluartikkelille, jossa tutkija oikoisi hätäisten ja sivistymättömien lukijoidensa väärinkäsityksiä.

Algot Untolan tekijyyksien tuotannolle tutkimus tekee kunniaa. Väitös myös muistuttaa, miten kutkuttavia kirjailijoita suomalaisesta kirjallisuudesta löytyy. Toivottavasti Untola-tutkimus saa jatkoa, ellei Kurikan niin jonkun muun toimesta. Suurtuotannossa riittää pengottavaa.

\title{
Kirjoittaja
}

Päivi Koivisto, FT, Helsingin yliopisto, kotimainen kirjallisuus

(pakoivis[at]gmail.com)

\section{Kiven kirjeet hyvin toimitettuina}

Aleksis Kivi: Kirjeet. Kriittinen editio. Toimittaneet Juhani Niemi (päätoimittaja), Sakari Katajamäki, Ossi Kokko, Petri Lauerma, Jyrki Nummi. Ruotsinkieliset kirjeet suomentanut Juhani Lindholm. Suomalaisen Kirjallisuuden Seuran toimituksia I386. Helsinki: SKS, 2013. 426 s.

Kirjeet ovat Aleksis Kiven puutteellisesti tunnettujen elämänvaiheiden paras lähde. Melkein kaikki muu aineisto on kuulopuhetta ja muistitietoa, joka on kerätty talteen vasta Kiven kuoleman jälkeen. Sen pätevyyttä on ollut ja on vaikea arvioida. Kirjeiden kriittinen editio on korvaama- 
ton teos jokaiselle Kiven elämäkertaan perehtyvälle mutta hyödyllinen myös tuotannon tutkijalle. Kirjeet julkaistiin ensimmäisen kerran jo sukupolvia sitten eikä uusia ole sittemmin löydetty. Kriittisessä editiossa jokainen kirje on nyt ensimmäistä kertaa huolellisesti kommentoitu ja sanat tarvittaessa selitetty. Kiven kirjeet avautuvat lukijalle paremmin kuin ennen. Kirjeissä mainituista henkilöistä on pienoiselämäkerrat, on kartta Kiven Helsingistä, tiedot hänen matkoistaan ja maantieteellisestä elinpiiristään. Juhani Lindholm on suomentanut ruotsinkieliset kirjeet.

Teoksessa on lisäksi neljä perusteellista johdantoartikkelia: "Aleksis Kiven elämät" (Jyrki Nummi), "Mitä Kivi luki” (Yrjö Varpio), "Kivi ruotsin kielen käyttäjänä" (Mirja Saari) ja "Kiven verkostot kirjeiden kertomina" (Irma Sulkunen). Nummi tekee selkoa siitä, miten tutkijat aikojen mennen eri lähtökohdista ja eri tavoittein ovat Kiven elämän esittäneet ja tulkinneet. Luotettavan tiedon vähäisyys on mahdollistanut mitä erilaisimmat spekulaatiot koskivat ne sitten Kiven syntyperää, naissuhteita tai psyykeä. Tilanne muistuttaa, kuten Nummi toteaa, Shakespearen elämän kuvauksia. Varsinkin psykobiografinen traditio on tuottanut tuloksia, jotka ovat tutkimuksiksi puettuja arvailuja. Ihmisen psyyken tutkiminen uskottavasti kauan jälkikäteen vähien sattumalta säilyneiden, epäluotettavien dokumenttien pohjalta ei ole mahdollista.

Kaiken Kiven elämää käsittelevän kirjoittelun perusta ovat olleet V. Tarkiaisen Aleksis Kivi. Elämä ja teokset (1915) ja muut Tarkiaisen Kivikirjoitukset. Tarkiaisen positivistisen tutkimuksen tuloksia ei voi sivuuttaa, ja Tarkiaisen analyysit ja tulkinnat Kiven teoksista ovat nekin kestäneet hyvin aikaa. Tarkiaisen tervejärkinen ja oppinut teos on lajissaan klassikko. Veijo Meren laaja essee Aleksis Stenvallin elämä (1973) tähdentää Kiven vaiheiden yhteyttä ajan poliittiseen taisteluun. Havainto ei ole uusi mutta hyvin esitettynä se valaisee tapahtumia. Meren toinen väite, joka koskee Charlotta Lönnqvistin ja Kiven suhteen seksuaalisuutta, on arvaus, ei muuta.

Yrjö Varpion artikkeli kriittisessä editiossa kirjaa aiempia yrityksiä paremmin kaiken, mitä Kiven tiedetään ja mitä hänen hyvin perustein voi arvella lukeneen. Eri asia on, mikä hänelle kirjailijana oli tärkeää. Kivi luki paljon ja seurasi sekä kirjojen, teatterin että lehdistön avulla ajankohtaista kulttuuria. Klassikkoihin hän tutustui hyvällä ruotsin taidollaan, jonka Mirja Saari artikkelissaan osoittaa.

Viittaukset Homeroksen tai Shakespearen teoksiin Kiven tuotannossa on etsittävä 1800-luvun ruotsinnoksista. Niissä voi olla virheitä, puutteita ja vääriä tulkintoja. Kivi saattoi seurata Shakespearen näytelmien ruotsinkielisiä esityksiä Helsingissä, vaikka siitä ei olekaan varmaa tietoa. Renessanssiteoksista myös Don Quijoten ruotsinnos on ollut Kivelle tärkeä. Uudemmassa kirjallisuudessa esimerkiksi C.J.L. Almqvistin proosa lienee Kiveä kiinnostanut. Putkinotkon uudispaikan ohella myös Kuningattaren jalokivikorun romanttiset kerrontaratkaisut ovat voineet inspiroida Kiveä.

Kiven lukeneisuuden jälkiä teoksissa on paljon tutkittu ja löydetty. Tarkiainen oli siinäkin todellisuudentajuinen. Hän kirjoitti jo 1912, että "kirjallisten vaikutusten innokas etsijä saattaa helposti mennä liian pitkäl- 
le, unohtaa runoilijan mielikuvituksen saavan virikettä yhä samantapaisina toistuvista elämänmuodoista ja päätellä satunnaisen yhdennäköisyyden jo merkitsevän suoranaista kirjallista lainaa."

Kiven kirjeiden ymmärtämisen kannalta johdantoartikkeleista antoisin on Irma Sulkusen kirjoitus. Sulkunen selvittelee Kiven tapaa kirjoittaa kirjeitä erilaisille vastaanottajille ja sijoittaa kirjeet kirjoitusajan konventioihin. Näin perusteellisesti ei tätä Kiven tuotannon osaa ole ennen analysoitu. Kirjeet paljastavat Kiven elämästä ja henkilöstä, hänen vaiheistaan ajassaan ja yhteisössään, enemmän kuin mikään muu lähde. Sulkusen tulkinta ei pyri Kiven elämän kokonaiskuvaan mutta näyttää sen katkelmallisuudessaankin konkreettisena.

Kiven heikko taloudellinen tilanne muuttui vähitellen toivottomaksi velkaantuneisuudeksi. "Aikana, jolloin taloudellinen pystyvyys oli miehen mitta", Kivi "taloudellisesti muista riippuvaisena, apua häpeämättömästi pyytävänä ja sen saamista itsestäänselvyytenä pitävänä" herätti ympäristössään pahennusta.

Olisiko romanttinen taiteilijakäsitys voinut vaikuttaa kyvyistään tietoisen Kiven asenteeseen, että porvarillisten tuttavien ja ystävien velvollisuus ja etuoikeus oli aineellisesti tukea häntä? Kivihän sai jokseenkin kaiken julkisesti tarjolla olleen taloudellisen tuen ja lisäksi epätavallisen paljon tukea yksityisiltä inmisiltä. Hänen yrityksensä tulla toimeen kirjailijantyöllä oli toivoton. Olemattoman vähän hän silti kirjoitti ajan suomenkieliseen lehdistöön. Sen sijaan hän kirjoitti näytelmän toisensa jälkeen aikana, jolloin mahdollisuutta niiden esittämiseen ei ollut. Shakespeare ja draaman suuri arvostus lienevät siihen vaikuttaneet. Lean menestys antaa aavistaa, miten Kiven ura olisi voinut kehittyä, jos suomenkielinen ammattiteatteri olisi ollut olemassa.

Sulkunen osoittaa, että Kiven holtittomuus raha-asioissa johti sosiaaliseen syrjäytymiseen, joka vaikutti hänen asemaansa ja tukeensa kirjailijana. Ystävät kävivät vähiin, koska heistä tuntui, oikein tai väärin, että heitä käytettiin hyväksi. Sulkunen toistaa aiemminkin jo todetun: August Ahlqvist ei ollut Kiven tuhon ainoa syypää. Ehkä hän ei, Kiven kannalta, ollut tuhon valmistajana edes pahin. Kipeintä oli se, että luottamus niihin, joita Kivi piti tukijoinaan ja ystävinään, petti. Asiaa pahensi, kun Kivi tajusi, ettei ollut syytön luottamuksen menettämiseen. Kivi oli joutunut umpikujaan. "Kirjallinen ja taloudellinen katastrofi" kietoutuivat yhteen.

\section{Kirjoittaja}

Pertti Lassila, FT, dosentti, Helsingin yliopisto, kotimainen kirjallisuus

(pertti.lassila[at]kaapeli.fi) 